\title{
Other Patrons of Architecture
}

It might be expected that the presence of Strada and his huge collection of documentation in Vienna, his function as imperial architect and, not least, the example he set with his own house would have exerted some influence on the development of architecture in the lands directly ruled by his patrons. I will discuss a few items where a direct influence of Strada and his Musaeum seems discernible, in two cases sufficiently strong to warrant an attribution to him.

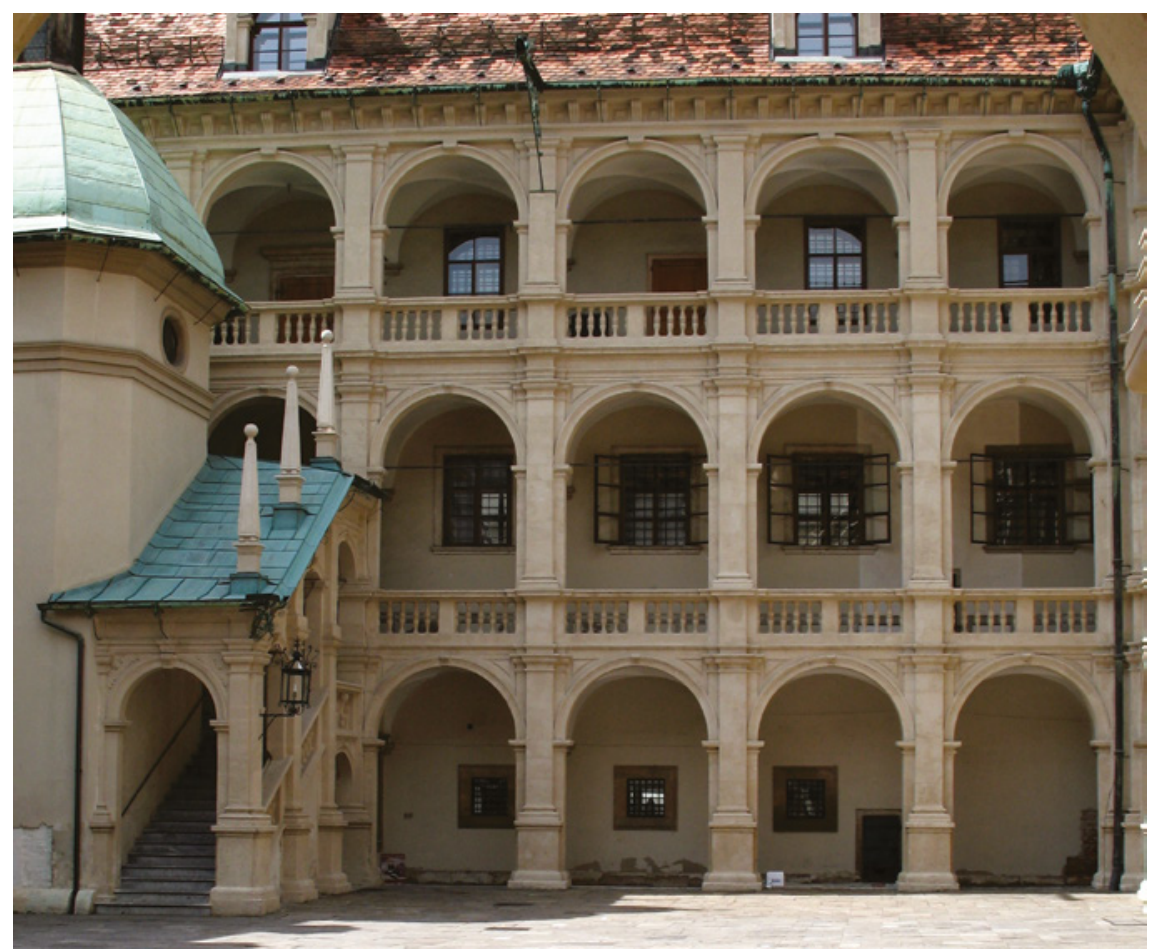

FIGURE 10.1 Domenico dell'Allio (?), courtyard of the Landhaus in Graz (ca 156o-1562).

\subsection{The Courtyard of the Landhaus in Graz}

In Chapter 5 I have paid brief attention to the Landhaus in Graz, which was built between 1557 and 1564 after designs and under the supervision of Domenico

(C) DIRK JACOB JANSEN, 2019 | DOI:10.1163/9789004359499_012

This is an open access chapter distributed under the terms of the prevailing CC-BY-NC-ND License. 
dell'Allio (ca 1515-1563). After Dell' Allio died in 1563 it was finished by his two assistants, Benedikt de la Porta and Peter Tadei. The Landhaus is one of the foremost monuments of the Renaissance in Austria, and Dell'Allio was a very talented designer, as is clear from the beautifully proportioned facade [above, Fig. 5.83]. He was one of the many Lombard engineers active in Italy, and his facade betrays his schooling in the Lombard tradition of the late Quattrocento and early Cinquecento: note the spacing of the windows, in particular the central bay, and the typical double window surrounds. It is clear that when Dell'Allio produced his design for it, he had not yet been exposed to more up-to-date design in the style of the Roman or Venetian High Renaissance. That seems to have changed in the last years of his life, witness the totally different character of the beautiful courtyard [Fig. 10.1]. This is surrounded by three levels of wellproportioned arcades carried on piers, on which is superimposed a carefully detailed order of pilasters, pedestals and entablatures, culminating in a cornice of protruding consoles carrying the roof.

In fact the difference with the facade is so great that one wonders whether Dell'Allio himself can have been responsible for it - if so, he must quite suddenly have been confronted with a more avant-garde style. Perhaps he paid a visit to one of the more advanced centres in Italy, such as Verona, Vicenza or Venice, where he could have seen some of the works of Sanmicheli, Palladio or Sansovino. But it might also be that he was made aware of more recent developments by a meeting with his newly appointed colleague at the Imperial court, Jacopo Strada, and a study of the materials in his possession. Probably Dell'Allio occasionally visited Vienna, or Strada made the acquaintance of Dell'Allio when spending a few days in Graz on his way to or from Venice. ${ }^{1}$

To my mind the similarity between the courtyard of the Landhaus and that of the Vienna Stallburg - which were built at exactly the same time-can hardly be a coincidence: together, they are the first two examples in Austria of a courtyard lined with arcades - a 'Laubenhof' - where the arches are carried on piers instead of on columns, and where the proportions are based on Vitruvian principles [Figs. 10.2-10.3]. Yet there are also significant differences: the Stallburg courtyard is very slight and sober, almost pedantically correct, with

1 Graz was a natural stop over in the habitual route Vienna-Venice and vice versa. Strada visited Venice in the late 1550 s to prepare his edition of Onofrio Panvinio's books, and probably also in the early 1560 s, when he travelled to Rome to buy antiquities for Hans Jakob Fugger. At the Landhaus Dell'Allio's patrons were the Estates of Styria, but as an engineer in fortification he was directly employed by the dynasty, for whom he also remodelled the Burg, their residence in Graz. It is perfectly possible that Strada would have taken the trouble to get acquainted with these buildings, and to meet his colleague, if available during one of his visits. 

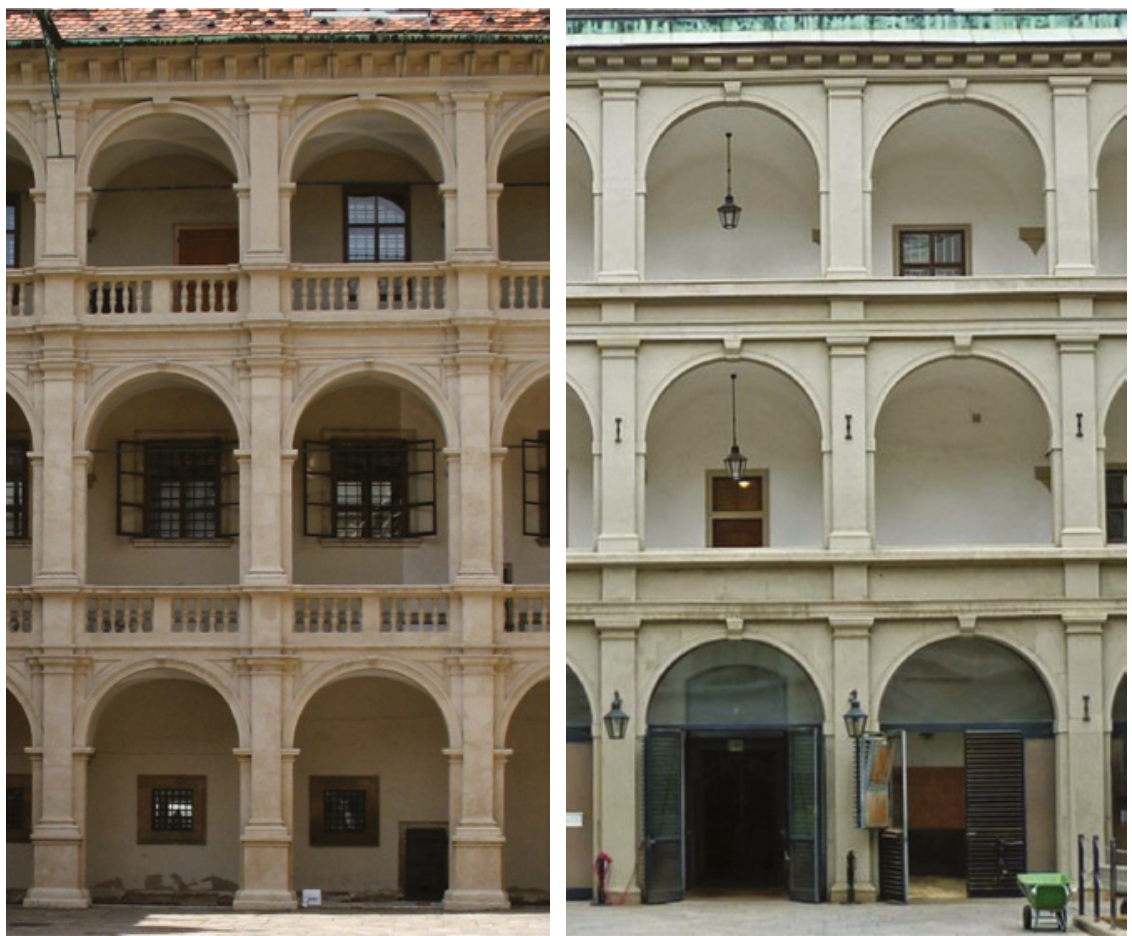

FIGURES 10.2-10.3 The articulation of the courtyard of the Landhaus in Graz compared to that of the Stallburg in Vienna.

very low relief; whereas the Landhaus courtyard seems to handle the Vitruvian precept with greater freedom and strives for greater monumentality and splendour. A quite fascinating detail is the superposition of two orders of pilasters, with a consequent reverse in the corresponding entablature, a motif possibly derived from Raphael's house for Jacopo da Brescia [above, Fig. 7.15]. It is difficult to decide whether the odd way in which the arches cut into the lower pilasters reflects a lack of detailed understanding of the rule that would characterize a provincial architect: in view of the general quality of the courtyard, I would rather read it as conscious, 'learned' playing with the rules, similar in spirit to Giulio's mannerist conceits in the facades of the Palazzo del Te. Of the two buildings I am confident the Stallburg can be attributed to Jacopo Strada, whereas the Landhaus seems to reflect a very different artistic personality. Yet their close relationship in time and in conception strongly suggests to me that the designer of the Landhaus - and the attribution to Domenico dell'Allio remains plausible — had been strongly influenced by the new materials he could 
have been shown, and the ideas he could have heard expound, by his new colleague at the Imperial court. ${ }^{2}$

\subsection{The Residence for Archduke Ernest}

In view of Strada's position as architect at court, and his bid for employment as an architect to Archduke Ernest, it is tempting to suspect his involvement in the first plans for the Amalienburg. From 1711 to 1742 the residence of the dowager Empress Amalia Wilhelmine, this building, on the north side of the Hofburg complex, was originally built as the residence for Archduke Ernest, who functioned as his brother's Lord-lieutenant in Austria after Rudolf II moved his court to Prague. At the time it was known simply as the 'Neue Stockh', 'das neue Gebeu <...> in der Burg', or even the 'Neue Burck'. Apart from the Stallburg, it constitutes the most voluminous addition to the Hofburg in the sixteenth century, yet the early history of this impressive block was until recently even less documented than that of the Stallburg. Thanks to Renate Holzschuh-Hofer's research within the framework of the Hofburg project, many open questions have finally been answered. ${ }^{3}$

The Amalienburg, Neue Burg or Ernestinische Trakt, was constructed on the site of the old Zeughaus or arsenal, a complex of several smaller buildings used for various practical, administrative and residential functions. For some of these Maximilian II had, shortly before his unexpected death, initiated modest repairs and extensions. These were continued by Archduke Ernest, and between 1582 and 1585 he had the whole complex, part of which he destined for his own residence, reconstructed and renovated. The use of the pre-existent fabric of the Zeughaus determined the odd, trapezium-shaped ground plan, but the elevation of the building was given a unified aspect, very simple and severe, and quite reminiscent of the Stallburg.

Its exterior, as can be surmised on the basis of two prints from 1598 and 1601 [Fig. 10.4], was as simple and severe as the exteriors of the Stallburg: a quite sober block consisting of two floors over a closed rustica zone, anticipating the later, still existent articulation of the façade. ${ }^{4}$ But its finish closely resembled

2 On the other hand a case could be made for an attribution of the design to Bonifaz Wolmut on stylistic grounds: the Landhaus courtyard is close in spirit to his Ballhaus and the organ loft in the Cathedral, both in Prague.

3 Holzschuh-Hofer 2014(d); the information available earlier summarized in Kühnel 1958, pp. 268-272 and Kühnel 1971, pp. 45-49.

4 The prints illustrate the executions of respectively Count Ferdinand von Hardegg (1595) (Stadtbibliothek Wien, Signatur A 3302, illustrated in Kühnel 1956, p. 229 and Tafel 1) and 


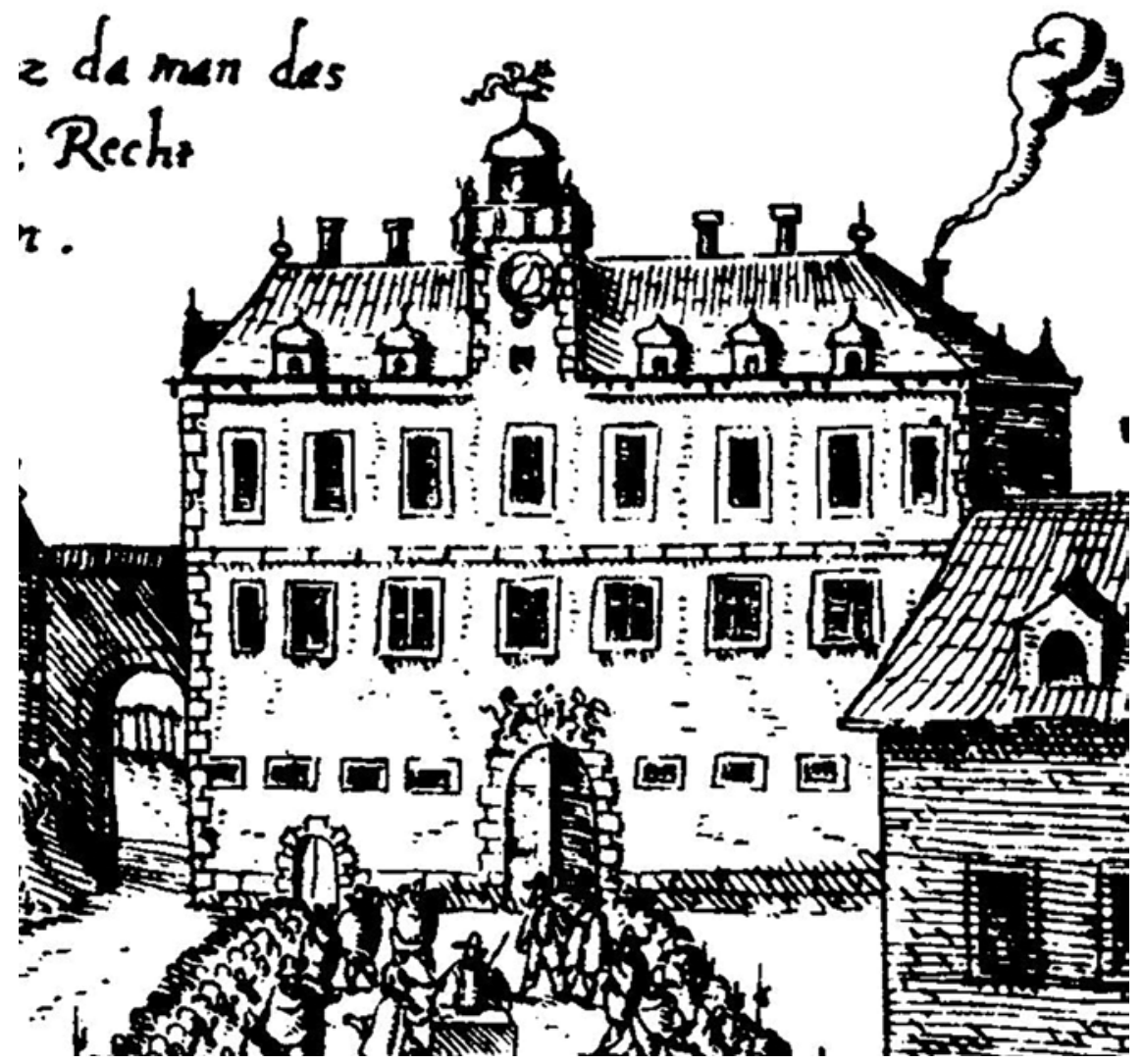

FIGURE 10.4 The Amalienburg, built as a residence for Archduke Ernest in the Hofburg at Vienna, detail of a print depicting the execution of Georg Paradeiser, 1601.

the Stallburg exterior, a plain stucco surface with stringcourses marking the levels, and heavy quoins accentuating the corners. The monumental entrance gate was topped by a coat of arms flanked by heraldic lions, and marked by a square clock tower rising above it.

Again like the Stallburg, three sides of its interior courtyard appear to have been faced with open arcades on all three levels. Its arches were carried on piers, which originally probably were articulated by a similar order of shallow pilasters or lesenes in masonry or stucco: at least that is suggested by the

Hauptmann Georg Paradeiser in 1601 (Wien, Historisches Museum, inv.nr. 96.646) (both commanders had been guilty of too easily surrendering a stronghold to the Turks). Samuel van Hoogstraten's view of the inner courtyard of the Vienna Hofburg (1652) in the Kunsthistorisches Museum, inv.nr. GG-1752. 
presence on the narrow northwest facade of strongly accentuated balustrades between heavy stringcourses, all in stone, which is all that remains after the loggias were closed and filled with windows. ${ }^{5}$

Since the first adaptations of the Zeughaus were commissioned by Maximilian II, it is possible that Strada may have been consulted on these, as he had been for other Imperial projects; but it is not known whether a unified new construction was envisaged already at that date. Possibly Strada's approach of Archduke Ernest in 1579, offering himself as a designer of palaces and gardens, may have been triggered by a rumour of plans for the construction of a Vienna residence of the Archduke, and initially he may have been involved in some consultative capacity. But the generic resemblance to the Stallburg provides too little basis for either a positive or a negative conclusion as to Strada's participation in its earliest designs. Moreover, the documents presented by $\mathrm{Dr}$ Holzschuh-Hofer make clear that the construction was supervised by Pietro Ferrabosco, who by this time surely may be assumed to have been capable of coming up with a competent design on his own account. So a direct involvement of Strada appears rather unlikely, though as elsewhere his influence and that of the graphic documentation of architecture he made available to his patrons and colleagues is unmistakable.

That is even true, though at one remove, for the present, more richly articulated facade of the Amalienburg, which was commissioned by Rudolf II in 1604. It was constructed somewhat in front of the original facade (as is clear from the position of the clock tower) and extended on the right with two additional bays; it continued around the corner and along the north façade, where it is still preserved in its original colour scheme. ${ }^{6}$ Its articulation, best seen in Samuel van Hoogstraten's painting of $165^{2}$ [Fig. 10.5], demonstrates a profound awareness of the architecture of Raphael and Giulio Romano. The style of this, for Germany, very unusual facade is reflected in the manor house at Dürnstein [Fig. 10.6], which is dated 1630, and is an equally sophisticated example of the careful reception of the architecture of the Roman High Renaissance, in particular of Raphael's Villa Madama. By this time such reception need no longer be derived from Strada's presence: both Dürnstein (sometimes attributed to Cipriano Biasino, 1580-1636) and the Amalienburg facade were designed by architects who probably knew Italian architecture-including that of Sanmicheli, Palladio and Scamozzi - at first hand. Yet Strada's presence prepared the way for the acceptance of this intellectually demanding style among at least a few of the patrons of architecture in Austria, as will be shown below.

5 Illustrated and reconstructed in Holzschuh-Hofer 2014 (d), Abb. IV.180-181.

6 Ibid., p. 345, Abb. IV.183. 

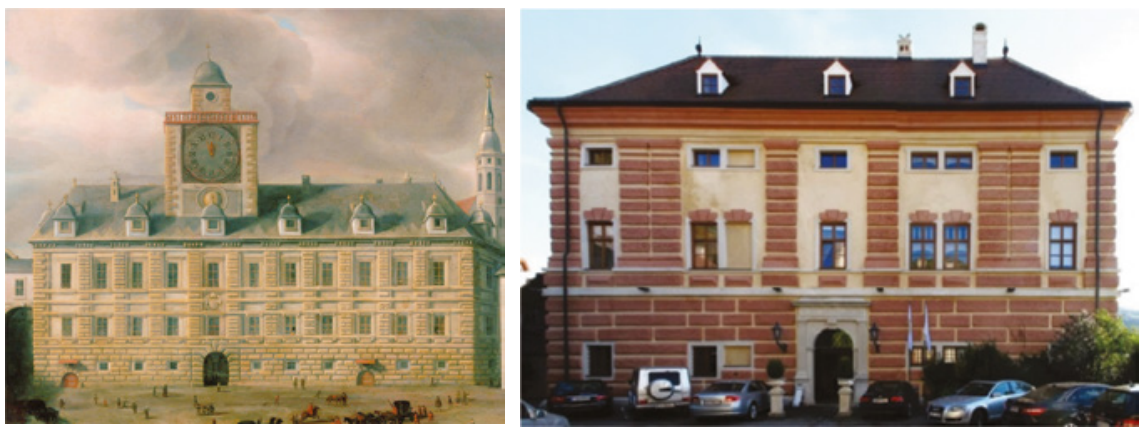

FIGURE 10.5 The Amalienburg in the painting by Samuel van Hoogstraten, 1652; Vienna, Kunsthistorisches Museum.

FIGURE 10.6 Cypriano Biasino(?), Schloss Dürnstein, 1630.

\subsection{Other Patrons: Vilém z Rožmberk}

From a survey of Strada's emoluments as court antiquary and architect it appears that his employment at court only provided a part, probably no more than a small part of his income. ${ }^{7}$ Nevertheless his position was of great advantage because of the prestige it accorded to him personally, and to the services and products he could offer other patrons. Moreover the court itself provided a lucrative market: a trendsetting community of individuals many of whom were well educated and shared many of the basic assumptions informing Strada's activities; who were rich, or at least needed to appear so; who were competing with one another in prestige and, as members of the imperial household, were in any case expected to contribute to the splendour of the court; and who were therefore willing to invest in display and other activities or objects that would enhance their prestige. Strada's house and Musaeum, which was a minor cultural centre in itself, was an explicit advertisement of the ways in which he himself and his workshop could satisfy such needs.

Strada's house and his collection would in any case be accessible at least to the higher-ranking members of the court. Just as his collections probably influenced the Emperor himself and his architects when planning the Stallburg and the Neugebäude, they must have influenced those members of the imperial entourage who themselves engaged in constructing houses in town or on their possessions in the country. In those cases they would have profited from Strada's comment on the materials he showed them, and from his informal advice on their projects. It can be expected that some of them would also have

7 Cf. Jansen 1988(c); slightly revised English version: Jansen 1992. 
asked Strada to provide plans and designs, especially from about 1568 onward, when his own house was sufficiently finished to show what he was capable of. We have few concrete data, but there is sufficient circumstantial evidence to support the hypothesis that Strada was directly involved in projects undertaken by four different patrons in Austria and Bohemia.

The first and most prominent of these is Vilém z Rožmberk (1535-1592), perhaps the grandest nobleman of Bohemia and as Oberstburggraf of Prague one of the highest ranking officials in the kingdom [Fig. 10.7]. Strada had some contacts with him, as is clear from a letter of December 1573, mentioning that Strada had recently seen Rožmberk in Prague. He tells him that he is obliged to sell his house and library to be able to have his books printed, and offers it first to Rožmberk 'as my gracious Lord and patron'; he tells Rožmberk that he will give him a better price than others, 'because of your longstanding patronage and the daily favours your grace grants me, equalled by no other Prince whomsoever. ${ }^{8}$ Apart from a drawing of the complete relief on the shaft of Trajan's Column in Rome which Strada had sold to Rožmberk and which is mentioned in the letter, we do not know what was implied in this 'Kundschaft'that is 'patronage'.

The tone of Strada's letter suggest that it had been no minor act of patronage, and that idea is reinforced by the fact that Strada dedicated his 1575 edition of Serlio's Settimo Libro to Rožmberk [Figs. 10.8-10.9]. That in itself might suggest that Rožmberk had at one time employed him in his building projects, which Strada refers to in a rather general way, praising Rožmberk for

the fishponds you have had dug, the most sumptuous palaces $<\ldots>$ you have had built, and in the first place that outstanding palace that, contracting two other large buildings into one, you had constructed on the castle of Prague itself' [Fig. 10.10].

But Strada continues that he dedicates Serlio to Rožmberk, just because 'at present I cannot myself serve your Excellency in this matter' - that is, architecture - and he does not mention any concrete services in that field he might have provided earlier. ${ }^{9}$ If Strada had earlier provided designs for any major part

8 Doc. 1573-12-18: 'als meinem gnedichen Herrn'; 'von Wegen der alten Kundschaft unndt deglige Dienst die mir Euer Gnaden thuen, der kainem Firsten, er sey gleych wer er wel'. Strada had been in Prague quite recently, sometime in the autumn of the same year.

9 Serlio 1575 , f. a ii verso: '<...> alios praeficit effodiendis piscinis: alios sumptuosissimis aedificiis (quibus impensè delectatur) erigendis, et in primis in palatio illo eximio, quod in ipsa arce Pragensi ex duobus alioqui magnis aedifcijs in unum coeuntibus, extruit. Qua in re quum Excellentia tuae praesens inservire ipse non possem, mitto, dono, ac dedico hunc septimum librum Sebastiani Serlij <...>' 

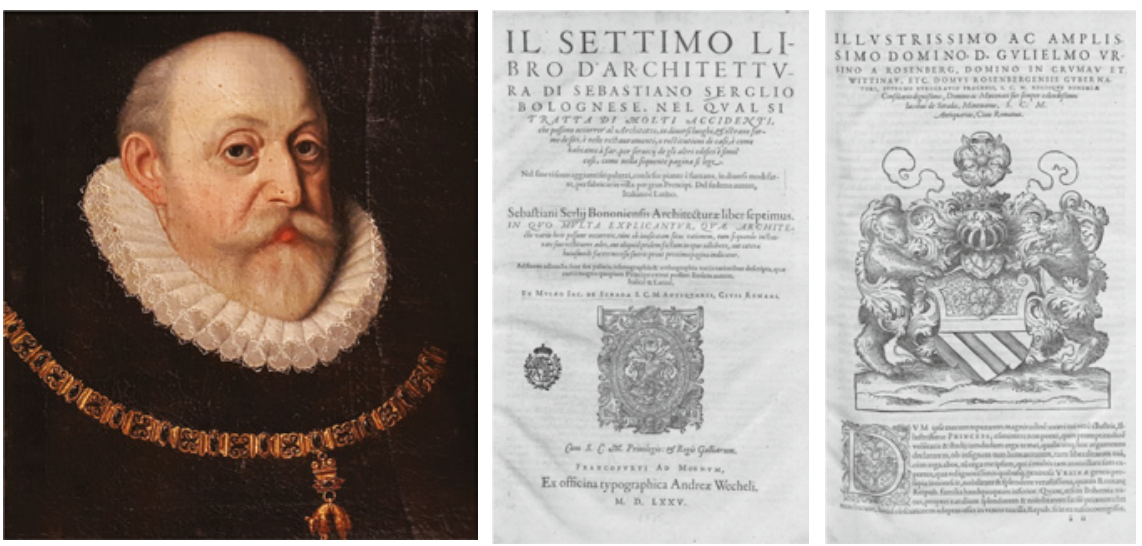

FIGURE 10.7

Anonymous, Portrait of Vilém z Rožmberka: Český Krumlov, Castle.

FIGURES $10.8-10.9$

Title page and Jacopo Strada's dedication to Vilém z Rožmberka of his edition of Sebastiano Serlio's Settimo Libro, Frankfurt 1575.

of the Rožmberk palace on castle hill in Prague, it seems likely that he would have mentioned it on this occasion. ${ }^{10}$ So it may well be that he merely contributed documentation on other ancient monuments besides Trajan's column, and had purveyed other books, prints and drawings and other collectibles: that at least is suggested by the apparent provenance from the Rožmberk library of

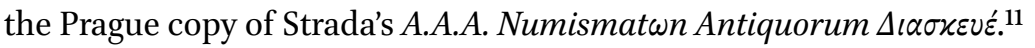

Since Vilém z Rožmberk had visited and stayed in Strada's house at some unspecified date, he had had the opportunity to inspect the documentation in Strada's collection and let himself be inspired by this. ${ }^{12}$ Possibly Strada's technical expertise, relating to mills, pumps, fountains and other waterworks may have been of interest to Rožmberk, as the owner of an extensive complex of artificial fishponds, which provided a substantial part of his immense revenue; but we have no concrete evidence for that. Neither do we have concrete

10 Jaroslav Pánek suggests that Strada may well have contributed to the plans of the Rožmberk palace in Prague, but does not provide further sources [Pánek 1989, p.258]; on the palace, see Krčalová 1970. Strada's name is not mentioned in Václav Březan's history of the Rožmberk family: Kubiková 2005 .

11 Prague, National Library, cod. vil A 1, a-l; inscriptions in the volumes documenting their provenance from the Jesuit College in Český Krumlov, combined with the initials 'W R' in each volume, strongly suggest that the book was commissioned or bought by Vilém z Rožmberk. In that case it is likely that Strada had also provided him with either a selection of authentic original coins or one or more of his albums of numismatic drawings.

12 In his letter Strada refers to Rožmberk's visit, when he had expressed the wish to buy the house whenever Strada would think of selling. 

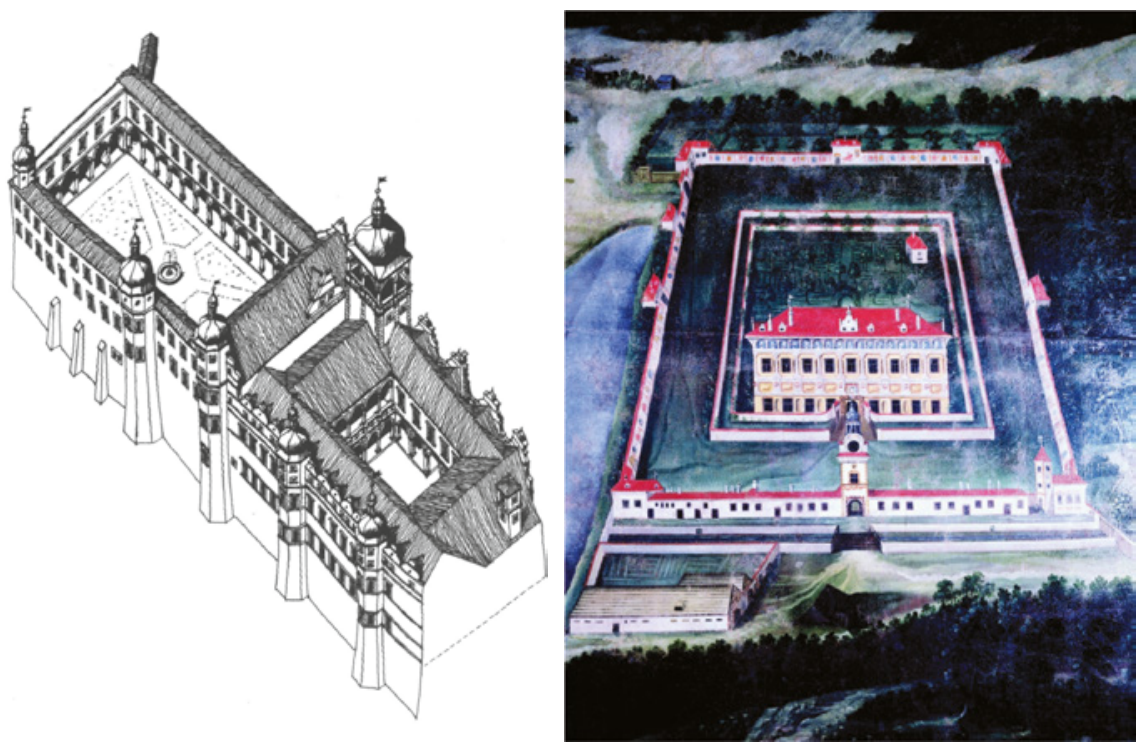

FIGURE 10.10 The Rožmberk palace on Caste Hill in Prague, restructured ca. 1554-1574; reconstruction drawing by Michael Brix.

FIGURE 10.11 Kratochvíle, built for Vilém z Rožmberka $1583-1589$ by Baldassare Maggi, in a painting by Jindřich de Veerle; Netolice, Kratochvíle Castle.

information about whether at a later date Strada may have been employed or consulted by Rožmberk in connection with his later projects, such as the charming country retreat Kratochvíle [or 'Kurzweil', that is: 'Pastime'], built between 1583 and 1589 near Netolice in Southern Bohemia [Fig. 10.11].13 Certainly Strada maintained contact with Rožmberk, who in 1576 had written a quite friendly recommendation for Strada to the Elector August of Saxony; and Strada was still corresponding with Rožmberk's secretary, Václav Březan, in 1585 . Yet there are no concrete data at all on Strada having been directly involved in Rožmberk's projects, and neither do we know of contacts between him and the architects who realized these projects, such as Ulrico Aostalli and Baldassare Maggi. My conclusion would be that Rožmberk indeed was a patron of Jacopo Strada, but that his patronage was mostly directed towards his library and collections, though it may have included some general, informal advice on the architecture and decoration of Rožmberk's residences.

13 On Kratochvíle, see Jakubec 2012. 


\subsection{Jan Šembera Černohorský z Boskovic and Bučovice Castle}

Just as Strada had business dealings_-'Kundschaft' — with Vilém z Rožmberk he had business dealings with one of the principal noblemen in Moravia, Jan Šembera Černohorský z Boskovic (1543-1597). Strada spent several months at the end of 1583 and the beginning of 1584 at the latter's newly built country seat at Bučovice, near Slavkov (Austerlitz) not far from the Moravian capital Brno, 'meiner geschäffte halben'- that is, for business reasons. ${ }^{14}$ On the basis of the notes of an archivist of the early nineteenth century, it has been assumed that a first estimate of the cost—and thus probably also a plan or design for this building — had already been made in 1567 by Pietro Ferrabosco; if so, that plan was executed by the Brno architect Pietro Gabri only in the 1570s, whereas the last section, the south wing, was only begun in 1579 , after a change in plan doubtless due to lack of funds [Figs. 10.12-10.13; 10.21]. ${ }^{15}$ The west wing carries a stone with the date 1581 , and by the time Strada was at Bučovice the windows were being glazed.

As Lietzmann has pointed out, this strongly suggests that Strada was advising Jan Šembera $\mathrm{z}$ Boskovic on its interior decoration. The ground floor of the west wing includes a suite of five modestly-sized but quite sumptuous rooms decorated with painted panels, partly painted on wooden panels, partly onto the plaster, set within stucco frames surrounded by painted grotesques, the
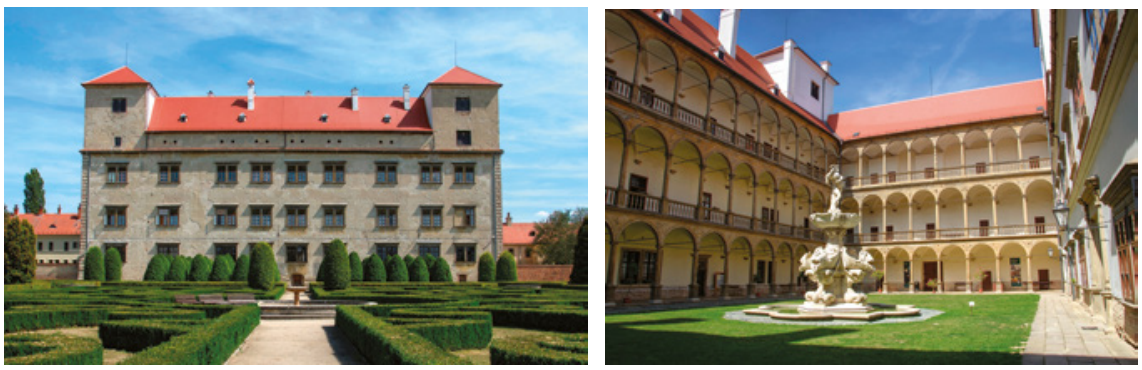

FIGURES 10.12-10.13 The castle at Bučovice: west- or garden front and courtyard.

14 We only know of this long visit because Strada was taken dangerously ill, and had himself carried to Brno for medical attention, where he drafted the first version of his will in April of 1584: Docs. 1584-1584-04-30; the definitive version of the will made up in Vienna on July 1st of the same year, Doc. 184-07-01. Cf. Jansen 1987, pp. 16 and 21, n. 71; Lietzmann 1987, pp. 133-134.

15 On Bučovice, see Krčalová 1969; Krčalová 1979; Vacková 1979; Hubala 1983; Hubala 1983; Renaissance in Böhmen, pp. 154-163; Lietzmann 1987, pp. 133-134 and 156-160. 

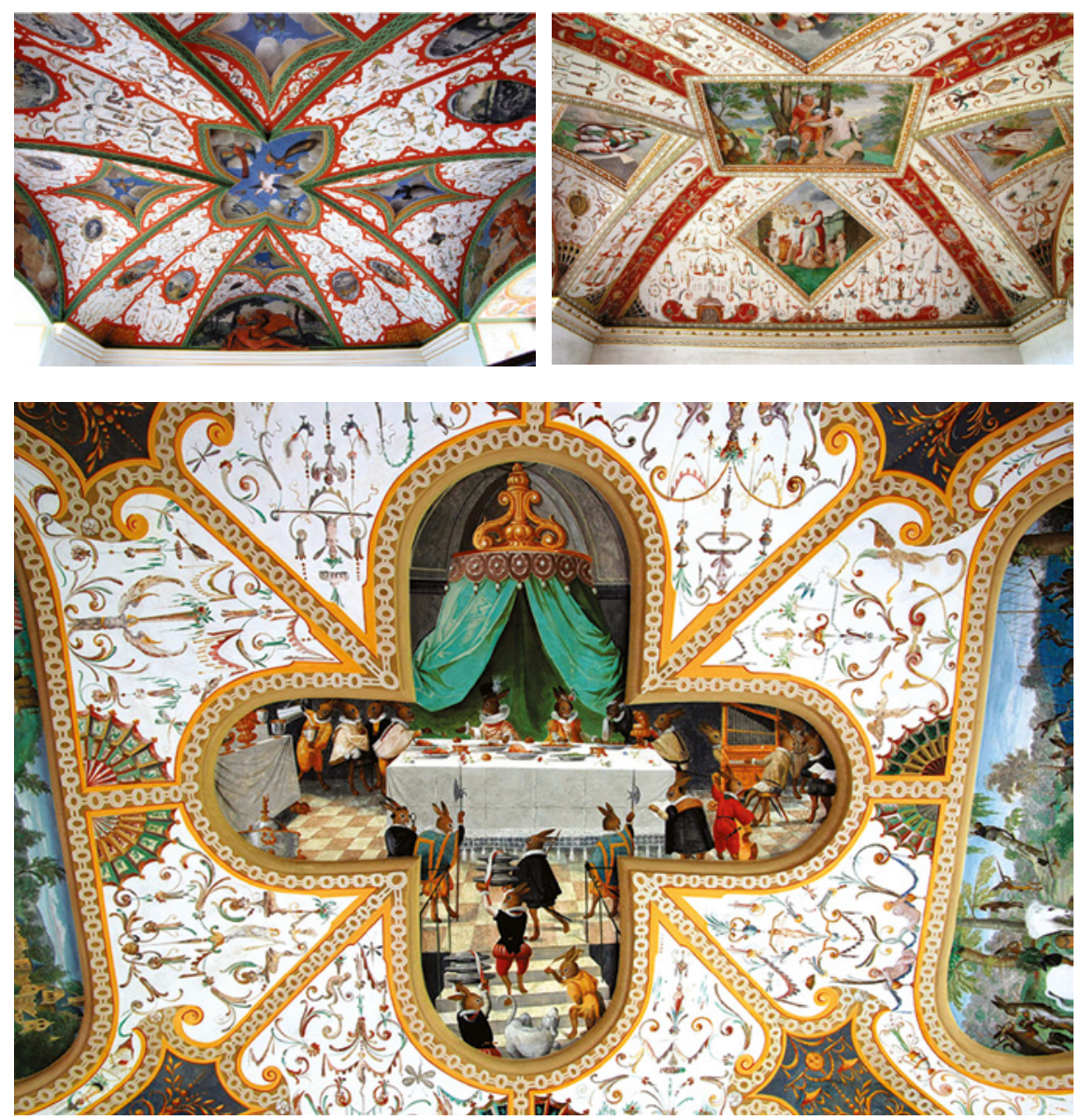

FIGURES 10.14-10.15 Bučovice, the Chamber of the Birds and the Chamber of Venus.

FIGURE 10.16

Bučovice, a detail of the decoration of the Chamber of the Hares.

latter quite elegant and quite Italian in spirit [Figs. 10.14-10.16]. In two of the rooms these decorations are complemented by sculpted figures.

In particular the Imperial Chamber, the central and most splendid of the five, may very well have been conceived by Jacopo Strada, not only because of its theme, but also because of its style [Fig. 10.17-10.20]. The division of its ceiling is adapted from the Camera degli Imperatori or the Camera di Attilio Regolo in the Palazzo del Te, but the style of the stucco decorations, especially the frames of the round medallions, are very close to similar stucchi in the Palazzo Ducale in Venice which Strada would have known from his visits in the 1560 . The four plaster busts of the Emperors Augustus, Nero, Antoninus Pius and 

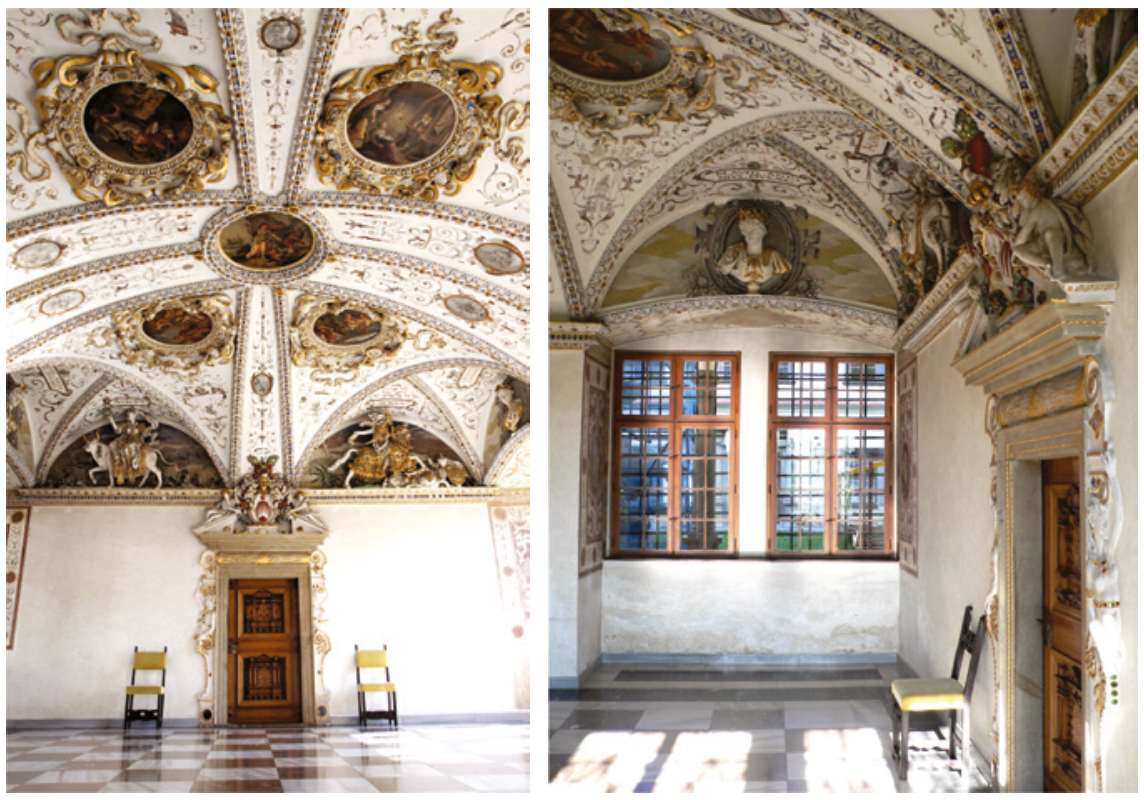

FIGURES 10.17-10.18 Bučovice, two views of the Imperial Chamber.
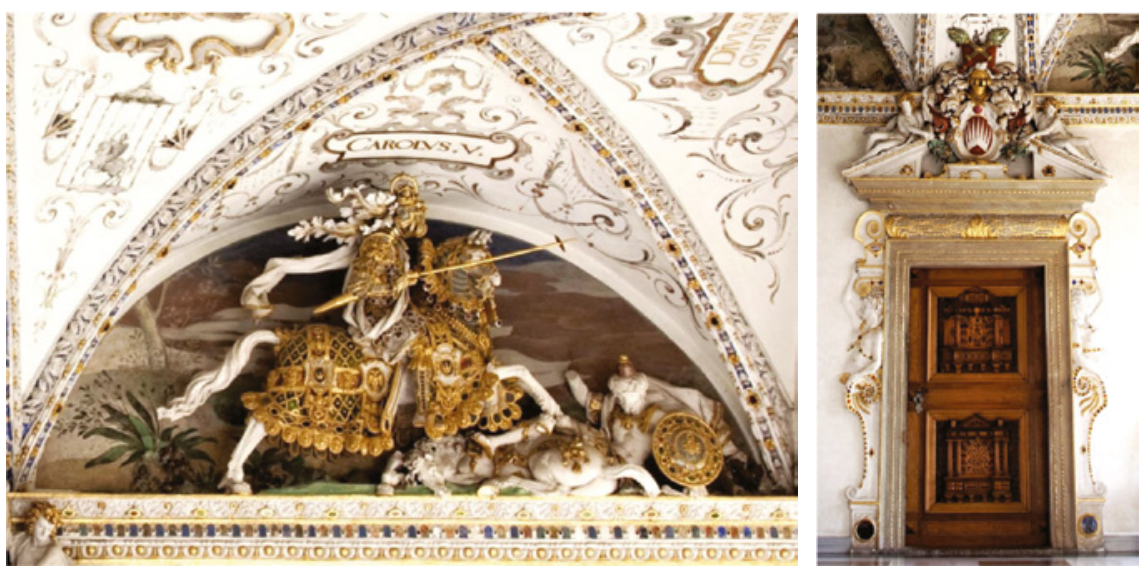

FIGURES 10.19-10.20 Bučovice, two details of the Imperial Chamber: Charles V vanquishing the Turks and the portal with the coats of arms of Jan Šembera Černohorský z Boskovic.

Marcus Aurelius placed over the windows were probably based on or cast from models provided by Strada himself [Fig. 10.18].

Jarmila Vacková has found out that the full-length figures in the lunettes, representing Europa, Mars, Diana and the Emperor Charles v [Fig. 10.19], are 
not executed in stucco but in terracotta pressed into a mould, while other elements are actually in wood, metal and glass. ${ }^{16}$ These are techniques that were used in the ephemeral decorations made, for instance, for the triumphal entry of Rudolf II in Vienna in 1577, which are described in Van Mander's life of Bartholomaeus Spranger, who together with Hans Mont was responsible for them. ${ }^{17}$

It has been plausibly suggested that the decoration of these rooms more or less reflects the decoration prepared by Spranger, Hans Mont and Giulio Licinio in Maximilian II's Neugebäude, and that Hans Mont may therefore be held responsible for the sculptural parts of the decoration at Bučovice. It seems very likely indeed that Strada, asked to devise the decoration of these rooms, would have fallen back on one or more of the artists he knew personally as close colleagues in Vienna, and with whom he probably had collaborated both at the Neugebäude and in one or more of the festivities organized at court. Given his presence at Bučovice for several months just at the time these decorations were realized, I think it is safe to assume that he had been charged with organizing and supervising the decoration of this cycle of rooms, which probably was intended to serve as its patron's studiolo and to house his library and collections. On the basis of the particular theme and its style, I am also inclined to attribute the design of the Imperial Chamber to him. ${ }^{18}$

Strada's presence at Bučovice at the time these decorations were executed obviously also raises the question whether he may earlier have had some role in the design of the castle itself. In her monograph on the Neugebäude Hilda Lietzmann was the first to propose him as its architect, instead of Ferrabosco,

16 She cites an unpublished restoration report of 1952, and investigated the room herself with specialist assistance (Vacková 1979, pp. 241-242).

17 Van Mander 1604, fol. 272r. 'Hier toe maeckte hy oock eenighe groote beelden van acht oft neghen voeten hoogh, eerst opgheraemt van hort hoy ghebonden, en daer nae met pot-eerde $\langle\ldots .$. , alle de beelden van aerde wesende, werden geschildert wit van Oly-verwe, datse glans hadden als witten Marber'.

18 A general survey of the decoration in Krčalová 1969, pp. 190-192; on the Imperial Chamber, see Royt 1997. These rooms merit a more detailed investigation, also as to their remarkable iconography and its sources: the Chamber of the Five Senses appears to be based on a set of 1581 prints by Raphael Sadeler after Martin de Vos; the Chamber of the Birds uses princely emblems such as those later printed in Ottavio Strada's Symbola; the Chamber of the Hares is probably inspired by a cycle painted a few years earlier by Heinrich Krönung in the Hasensaal, the principal reception room of the Augustusburg, a splendid Renaissance hunting residence built by the Elector August of Saxony only a few years earlier, which itself was based on Georg Pencz' woodcut to a poem by Hans Sachs, printed already in 1535 . 
whose links with Bučovice are questionable in any case. ${ }^{19}$ At first sight this is an attractive proposition: Bučovice is one of the most carefully designed Italianate mansions in the Habsburg dominions [Figs. 10.12-10.13 and 10.21]. Its lay-out clearly represents an early version of the 'palazzo in fortezza', that is a manor house designed on a plan or protected by outworks that imitate modern, Italianate fortification, such as those planned by Antonio da Sangallo around the Farnese villa at Caprarola and illustrated in various versions in Serlio's Sesto Libro. ${ }^{20}$ It had already inspired other castles in Bohemia, notably Nelahozeves (Mühlhausen), built from 1553 onward on the banks of the Vltava north of Prague for Florian Griespek von Griespach (1509-1588), secretary of the Bohemian Chamber. ${ }^{21}$ At Nelahozeves the corner towers of the house itself are shaped as bastions, that is, the castle itself was planned as a fortress; in other versions, such as Bučovice and, slightly later, at Vilém z Rožmberk's country house Kratochvíle [Fig. 10.11], a more straightforward manor house and its garden is set within an enclosure protected by a curtain wall and bastions at the corners and surrounded by a moat.

19 It is not clear whether the lost documents reported by the Liechtenstein archivist actually mentioned Ferrabosco's name. 1567, when Jan Šembera was only twenty-four years old, seems rather early for the huge project as was finally realized: (copies of) documents recording building activities from 1575 and 1579 have been preserved, and its main fabric seems only to have been finished by 1583 . It is perhaps more likely that Bučovice was built according to plans made after 1572, when Jan Šembera's elder brother Albrecht died without issue, and he became the head of his illustrious family (of which he also would be the last male representative). Krčalová 1969, pp. 183-188, sums up Ferrabosco's documented activities, exclusively imperial commissions, in which he was very strenuously occupied (both in military and civil architecture; in 1566 and 1567, when he would have made the plans for Bučovice, he was chiefly occupied with fortifications in Hungary ). One wonders whether he would have time and occasion to work for private patrons.

20 On the palazzo in fortezza, see Frommel 1999. The citadel of Jülich was one of the earliest versions north of the Alps, though it is perhaps not quite representative of the type, since here the citadel is a very serious, complete and very up to date fortress. Serlio's relevant projects in the Munich ms. of the Sesto Libro, вsB-Hs, Cod. Icon. 189, ff. 16v-18r: 'Della casa del principe illustre a modo di fortezza' (an Italianate version of his design for Ancy-le-Franc); idem, ff. 18v-19r; ff. 25v-27r: 'Della casa del principe illustrissimo per fare alla campagna'; ff. $27 \mathrm{v}-29 \mathrm{r}$.: 'Della casa del principe Tiranno per far fuori alla campagna'; ff. 29v.-31r.: 'Della casa del principe tiranno di un altra forma' (a variation on the Villa Farnese at Caprarola). Even more or less cosmetic fortifications such as that at Bučovice did have a practical defensive function, witness the fact that sometime during the Thirty Years' War the house withstood a siege by a marauding Protestant army (which burnt the village instead).

21 Griespek was a very avant-garde patron of architecture, on his two beautiful creations at Kaceřov and Nelahozeves, cf. Erich Hubala, 'Die Schloßbauten des Florian Griespeck in Katzerow und Mühlhausen', in Renaissance in Böhmen 1985, pp. 63-105. 



FIGURE 10.21

Reconstruction of the original appearance of Bučovice.

FIGURES 10.22-10.23 Sebastiano Serlio, design for a palace for an illustrious prince in the countryside, from the Munich ms. of the Sesto Libro.

Both types are represented in Serlio's Sesto Libro: the example closest to Bučovice, both in form and in function, is his project $\mathrm{nr}$. $\mathrm{x}$, 'Della casa del principe illustrissimo per fare alla campagna' [Figs. 10.22-10.23]. If Serlio provided the inspiration for Bučovice, as seems likely, Strada must of necessity have been the intermediary, since the Sesto Libro was never published. So Lietzmann's intuition that Strada was in some way involved in the project in the 1570s, or perhaps even earlier, seems rather plausible.

But though it seems likely that Strada advised or even coached the patron of Bučovice or his architect, which might well explain the systematic rigor of the planning of the castle, I think it rather unlikely that the actual design was due to him. My doubts are due in particular to the colonnades, where the arches are carried directly on single columns, without entablature whatsoever [Fig. 10.13]. Though these arches and the columns that support them are wellproportioned, in Italy this would be a quite old-fashioned solution by this time. I would have expected Strada to have opted, as at the Stallburg, for the more 
correct solution of piers carrying the arches. Moreover it is difficult to accept that Strada would have agreed with the asymmetrical division of the windows in the west or garden wing, which spoils the monumentality of this otherwise quite grand facade [Fig. 10.12]. And finally the doubled windows, however classically detailed, appear to me to reflect a vernacular tradition: Strada doubtless would have opted for more classical, single, vertically spaced windows, as in his own house and in his design for the Antiquarium. So if Strada was involved in the design of Bučovice, his contribution probably remained limited to its planning, while the actual design of the elevation was left to Pietro Gabri, the North-Italian architect active in Moravia who was actually paid for building Bučovice.

\subsection{Christoph von Teuffenbach: The House in Vienna and the Castle at Drnholec}

Strada's house functioned as a clearing house for cultural information within the overlapping worlds of courtiers, diplomats, scholars, artists and merchants that made up and surrounded the Imperial court. This function, which will be investigated in greater detail in the next chapter, was of great importance to Strada, probably both for economic reasons and for reasons of personal and family prestige. To emphasize this function he kept a sort of guestbook in which his most important guests, in particular princes and great magnates, were asked to write their name, which he then complemented by a carefully illuminated illustration of their coat of arms. His second son, Ottavio, perhaps imitating this procedure, kept a personal album amicorum or Stammbuch, in which he asked his aristocratic acquaintances to write their names. ${ }^{22}$

I have often wondered where Strada took the idea of having such a guest book for his Musaeum, and why his son Ottavio, who never studied at a university, nevertheless kept a Stammbuch, a typically German tradition that had only very recently originated at the Protestant universities. ${ }^{23}$ I was alerted to a plausible solution by an article by Günther Buchinger, Paul Mitchell and Doris Schön of the Vienna Denkmalamt, which presents the results of their research into the building history of the so-called Concordia house. Situated at nr 8 of the Bankgasse, opposite the Stadtpalais Liechtenstein in Vienna, this was at one time the next-door neighbour but one of the house of Jacopo Strada. Though

22 On Jacopo Strada's guest book and his son Ottavio's Stammbuch, see below, Ch. 11.1; Jansen 1992, pp. 199-201.

23 On Stammbücher in general, see Fechner 1981; Klose 1982; Klose 1989. 
its facade dates from the late seventeenth-century, its basic fabric dates back to the period when it was originally built by Christoph von Teuffenbach, Freiherr von Mairhofen, after his acquisition of the site sometime in $1568 .^{24}$

Teuffenbach, a member of a Protestant Styrian noble family, studied with Melanchton in Wittenberg, where he matriculated in 1546. He began his military career under the aegis of the Imperial General Lazarus von Schwendi and fought against the Turks in Hungary. In 1567 he was sent, with Antun Vrančič and Albert de Wyss, as ambassador to the Sultan, Selim II, with whom they negotiated the truce of Adrianople (1568). Upon his return he served as a diplomat and a military commander in Hungary, jobs in which he was quite successful. He died in 1596, only a year after Hans von Aachen had painted-as a gift to its sitter - a splendid portrait which is lost, but known through Sadeler's attractive engraving [Fig. 10.24].$^{25}$ Strada's probable contacts with his nearneighbour may provide a neat solution to my problem: as Teuffenbach's own Stammbuch is an early example of the type, he could well have provided the inspiration for Jacopo's guest book and Ottavio's album amicorum. ${ }^{26}$

It is very suggestive that Teuffenbach began building his house next door to Strada at a time when Strada's own house neared at least partial completion. Though its facade dates from the late seventeenth century, from the research by Buchinger cum suis it results that its basic fabric dates back to the period when it was originally built. I have found no documents proving that the two neighbours and fellow-courtiers discussed their projects together, but some such informal exchange doubtless has taken place. Teuffenbach, who was a soldier, a diplomat and an intellectual, would have been curious to consult the architectural material in Strada's possession and discuss his plans with him, while Strada would have been eager to merit the good graces of an influential courtier, as well as willing to oblige a respected neighbour. Such compliance may have remained limited to comments and advice. Yet from the point of view of Teuffenbach, it would have made sense to ask Strada to prepare the drawings: in this way he would be assured of a quite up-to-date design, of which Strada's own house gave him already an idea. In view of his absence for

24 Buchinger/ Mitchell/ Schön 2006. But the Hofquartierbücher already mention it as the possession of 'Herr von Tieffenpach. Freyhaus' in 1863 [Birk 1869, p. 126].

25 Joachim Jacoby, Hans von Aachen, Rotterdam, 1996, nr. 101, pp. 219-222. The inscription on the print states: 'Sacra Caes: Mai.tis pictor Joan ab Ach pinxit, eidemque Fig. Dno. d<ono> d<edit>', i.e. 'The Imperial Painter Johannes von Aachen painted this and presented it as a gift to the same illustrious gentleman'. The print was often copied or adapted, among others for Dominicus Custos' portrait collection, Atrium Heroicum ... , of 1600-1602.

26 Salomon 1955; Klose 1989; Kurras 1989. On Teuffenbach: Schweigerd 1852, s.v. Teuffenbach, pp. 466-469; Wurzbach 1856-1891, 44, 1882, 44, pp. 63-65. 

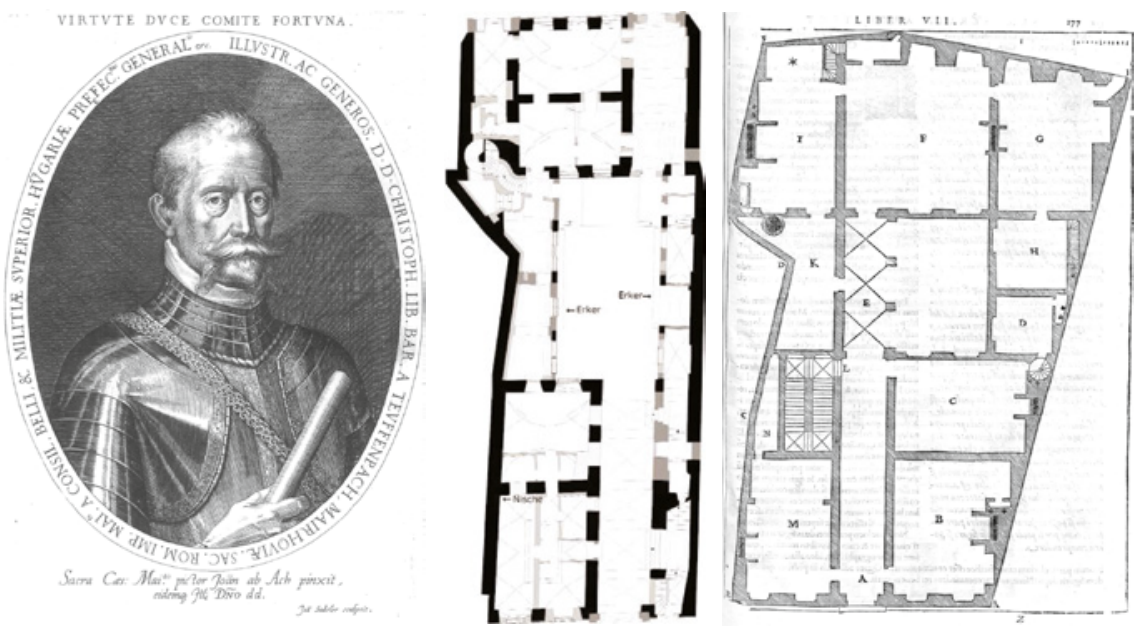

FIGURE 10.24

Johannes Sadeler, Christoph von Teuffenbach, engraving after a lost portrait by Hans von Aachen, 1595 .

FIGURES 10.25-10.26 Plan of the house built ca. 1565-1570 in Vienna for Christoph von Teuffenbach, compared to one of the projects for houses on an irregular site from Serlio's Settimo Libro (1575).
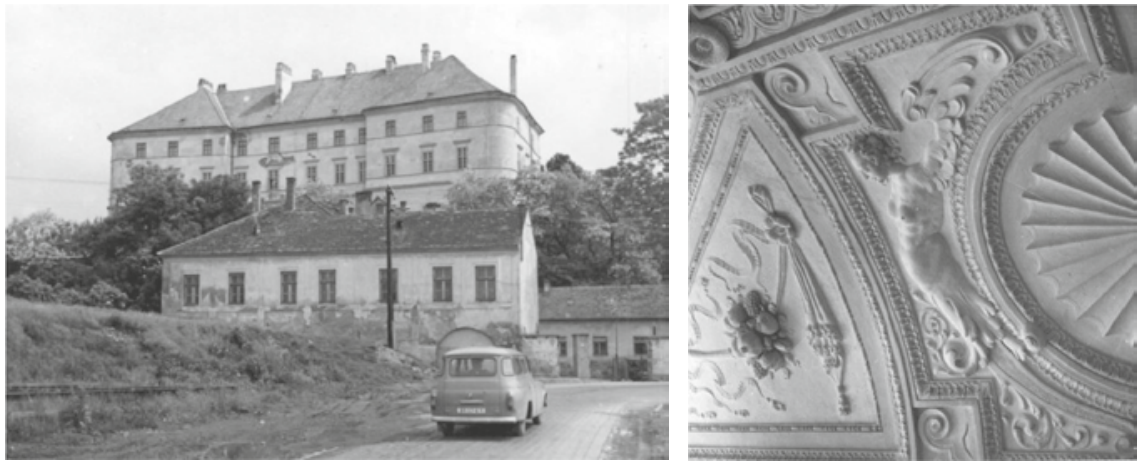

FIGURES 10.27-10.28 Drnholec, the castle built ca. 1583-1587 for Christoph von Teuffenbach, restructured in the late eighteenth century; and a detail of one of its stucco ceilings.

more than a year, it would be a great advantage that its designer was living next door, and could closely supervise the building's progress. Moreover Strada's connection with the Imperial building works would be favourable, making it easier to find labourers and specialized artisans and perhaps materials as well.

In any case the lay-out of Teuffenbach's house [Fig. 10.25], built on a site of irregular proportions, demonstrates an intelligent application of Serlio's proposals for building on irregular sites [Fig. 10.26]. These were included in 



FIGURES 10.29-10.30 Serlio's plan and elevation for a fortified palace for a 'principe tiranno' in the countryside, from the Munich ms. of the Sesto Libro.
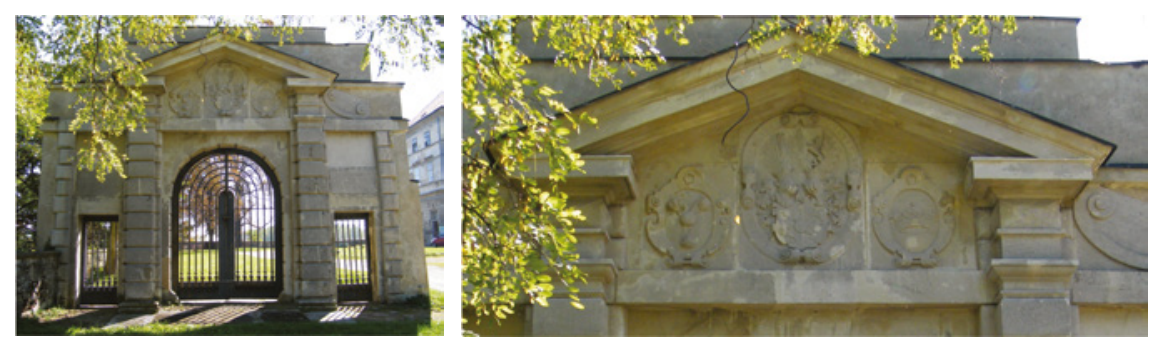

FIGURES 10.31-10.32 Drnholec, the entrance gate to the castle built for Christoph von Teuffenbach.

his Settimo Libro, the manuscript of which was in the possession of Strada, who was preparing it for publication. As we have seen above, his edition would come out only in 1575, with a preface of his own, and a dedication to another important patron, Vilém z Rožmberk. It is likely that Strada had offered access to his manuscripts to Teuffenbach and to his architect, whoever he was. But it would have been quite efficient if he had made the designs himself, and had made the crew he had already brought together to construct his own house available to Teuffenbach.

Some fifteen years later Christoph von Teuffenbach began building a huge mansion on his newly acquired manor at Dürnholz or Drnholec in Moravia. Also for this project it is possible that he may have had recourse to his Vienna neighbour and may have made use of the materials kept in his Musaeum. ${ }^{27}$ The castle itself has been largely reconstructed in the eighteenth century, but some of its basic structure has been preserved, witness the beautiful late

27 On Drnholec, see Hrady, Zámky a tvrze v Čechách, Na Moravě a ve Slezsku 1981, pp. 94-95; Samek 1994, p. 416-417. I am grateful to Ivan Muchka for having provided me with photocopies of these entries. 
sixteenth- and early seventeenth- century stucco ceilings that have recently been restored [Fig. 10.28]. With its quite huge bastion-like pavilions at the corners of the main block [Fig. 10.27], this again appears to be a variation on the 'palazzo in fortezza' type, perhaps based on Serlio's two related projects 'Della casa del principe tiranno per far fare alla campagna' [Fig. 10.29-10.30]. ${ }^{28}$

Any speculation as to Strada's possible involvement in the design for the main block must depend on future research providing more evidence as to its original appearance. Yet the castle preserves one feature relatively intact that does allow some further discussion: the entrance portal, originally part of the demolished gatehouse, which is dated 1583 [Figs. 10.31-10.32]. This is a beautiful example of Italian classical architecture, very close to Serlio and to Giulio Romano, and in its sobriety close to Strada's own house and the Stallburg. Considering that this is exactly the time that Strada was involved in projects at Bučovice, elsewhere in Moravia, I am tempted to tentatively attribute its design to him. In any case I think it can be considered as a prime example of the influence of Strada's presence and of the documentary materials available to his patrons in his Musaeum.

\subsection{Reichard Strein von Schwarzenau and the Castle at Schwarzenau}

There is still one more example where it seems possible that Strada's materials and his personal comments on them may have influenced one-or perhaps even more - of a patron's projects. The patron in question was Reichard Strein von Schwarzenau, a young and cultured member of one of the richest Protestant noble families from Lower Austria [Fig. 10.33]. ${ }^{29}$ Born in 1538, he had studied in Padua and Strasbourg, after which he soon became a trusted servant of Maximilian II, filling in quick succession ever higher posts. In 1567 , when he was only 29 years old, he became president of the Hofkammer, the principal financial official at court. Already at twenty-one he had published in Geneva a small treatise on the genealogies of ancient Roman gentes, and he continued this study with sufficient diligence to publish in 1571 a far more ample version, printed by Paulus Manutius in Venice, with a dedication to Archduke

28 Munich ms. of the Sesto Libro, BSB-Hs Cod. Icon. 189, fol. 27v-29r.

29 The name was and is also spelled Streun; I have opted for the spelling used on the titlepage of Reichard Strein's own publications (see following note); on Strein, see Grossmann 1929; Evans 1973/1984, pp. 127-128. 

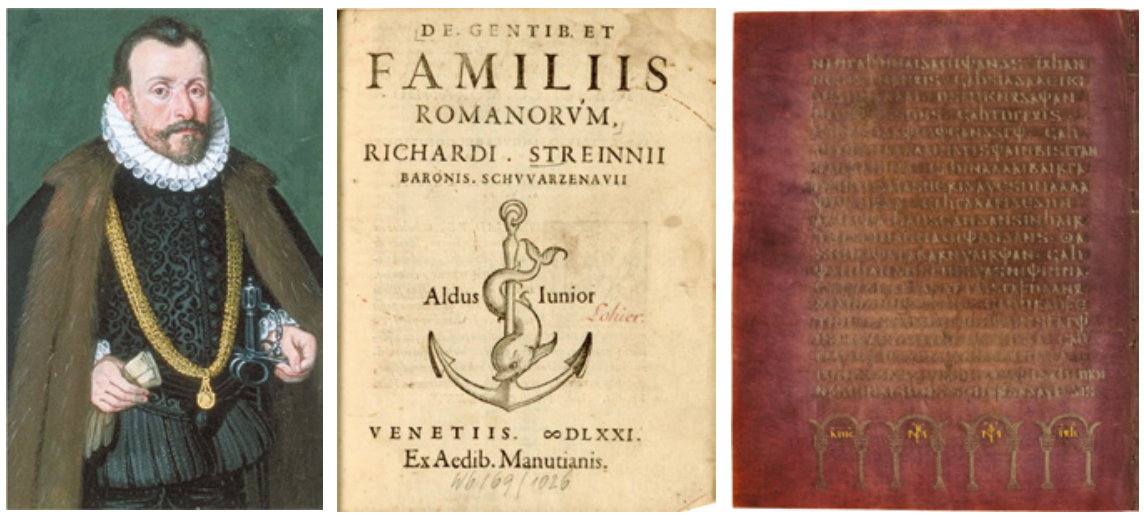

FIGURE 10.33 Anonymous, Reichard Strein von Schwarzenau, from the portrait book of Hieronymus Beck; Vienna, Kunsthistorisches Museum.

FIGURE 10.34 Reichard Strein's De gentibus familiis Romanorum, printed by Paulus Manutius in 1571.

FIGURE 10.35 A page from the Codex Argenteus, the Gothic bible translation acquired by Strein for the Imperial library.

Charles [Fig. 10.34].$^{30}$ His interest in Roman civilization also expressed itself in the acquisition of antiquities such as inscriptions and sculpture. ${ }^{31} \mathrm{He}$ was also interested in the history of the Late Roman Empire and its textual sources, and managed to acquire the famous Codex Argenteus, containing Wulfila's Gothic Bible translation, for the Imperial library [Fig. 10.35]. ${ }^{32}$ In addition he published on the laws of his homeland, Lower Austria. In view of his interests and erudition it is not surprising that at one point his functions included the supervision of the Imperial library.

Merely in view of his position Strein would have had access to Strada's Musaeum, but sharing many interests it is possible that they maintained informal contacts - the more so because, just as Strada and Teuffenbach, they

$30 \quad$ Gentium et familiarum Romanorum stemmata. Richardo Streinnio barone Suuarzenauio auctore, [Geneva] 1559 (published by Henri Estienne with the type of Ulrich Fugger); De gentibus et familiis Romanorum, Venetiis [Aldus Manutius] 1571.

31 These included two inscriptions from Ravenna, which Strein had obtained from the collection of Matthäus Cardinal Lang von Wellenburg, Prince-Archbishop of Salzburg, and an inscription from Lorch (Lauricum); cf. Langeder 2009.

32 Now in Uppsala University Library; cf. Unterkirchner 1968, p. 72; cf. H.F. Massmann, 'Gothica minora' in Zeitschrift für deutsches Alterthum 1, 1841, pp. 294-393, esp. pp. 315-319; Dorothea Diemer, 'ein adenlichs hausgerette, und nit jedermans Ding': zum Schicksal des Codex Argenteus Upsaliensis im 16 Jahrhundert', in Diemer/ Diemer/ Sauerländer 2008, 3, pp. 331-344. 
were neighbours: Strein lived on the site of the present Palais Starhemberg, across the Vordere Schenkengasse, almost opposite Strada. ${ }^{33}$ That they did have contact on scholarly topics is clear from the fact that it was Strein who, in June 1573, presented Strada's request for letters of recommendation from the Emperor to various princes of the Empire, to induce them to subsidize the huge scholarly publishing programme he was setting up. ${ }^{34}$

Strein may well have been willing to promote Strada's scholarly projects in other ways. Thus it may have been through his recommendation that Strada came in contact with Henricus Glareanus and François Hotman, two of the teachers Strein had studied with, and whom he highly praises in the preface of his De gentibus. With Aldus Manutius the younger and Fulvio Orsini, whom Strada knew through his presence or contacts in Venice and Rome, these two outstanding scholars contributed to the first complete edition of Caesar's Commentaries, which Strada intended to publish in France, and for which he obtained a copyright privilege of King Charles IX on Christmas day of $1572 .{ }^{35}$

If they shared such interests and enthusiasm, it is obvious that-once Strein began planning architectural projects-he would have recourse to the documentation in his neighbour's Musaeum and to his expertise in this field. And Strein was planning architectural projects almost all the time: his family was very wealthy, and he and his brothers together owned and sometimes rebuilt something close to twenty-five castles and country houses in Lower Austria and Moravia. ${ }^{36}$

Reichard Strein's principal seat was the huge castle of Freidegg in Ferschnitz in Lower Austria, which he had almost completely reconstructed between 1575 and 1594 [Fig. 10.36]. Almost nothing of all this remains; the Streins died out in the seventeenth century and there are no family archives documenting the genesis of this or the other projects undertaken by Reichard. Nevertheless one of his creations is still standing, the ancestral seat from which he derived his

33 Grossmann 1927.

34 Doc. 1573-06-oo, Strada to the Imperial Vice-Chancellor Weber: 'Io creddo che la Signoria Vostra avera auto la mia suplica che'l Signor Strain à mandato avanti hieri alla Signoria Vostra'. On this project, see Jansen 2004, pp. 184-185 and below, Ch. 14.

35 On this edition, printed in Frankfurt in 1575, see Jansen 2004, pp. 189-191 and below, Ch. 14.5.3.

36 Recently discussed in Alena Skrabanek's outstanding master-thesis dedicated to the architecture of Ungarschitz/ Uherčice, the one substantial estate the Strein family owned in Moravia: Skrabanek 2008, esp. pp. 35-38 'Exkurs: Genealogie und Herrschaftsstruktur der Streun von Schwarzenau' and pp. 39-40 'Exkurs: Nebensitze der Streun in Niederösterreich'. 



FIGURES 10.36-10.37 Two castles rebuilt for Reichard Strein von Schwarzenau, from Georg Matthäus Vischer's printseries Topographia Archiducatis Austriae Inf. modernae (1672): Schloss Freidegg (1575-1594) and Schloss Schwarzenau (1583?-1592).


FIGURES 10.38-10.39 Schloss Schwarzenau, views of the west or entrance facade and the south facade.

title, the castle at Schwarzenau in the west of Lower Austria, close to the Czech border [Fig. 10.37; 10.38-10.39]. ${ }^{37}$

It is not exactly known when it was begun, perhaps slightly later than Reichard's projects in Freidegg (1575-1594). The date 1592 on the sundial on one of Schwarzenau's towers is generally considered its date of completion-in view of the long construction period of Freidegg a projecting date for Schwarzenau in the early or the mid-1580s at the latest is plausible. Schwarzenau is a very big house, which was built largely ex novo according to a rigorous, symmetrical plan; its main focus is the wide entrance facade on the west, which is flanked

37 Daim/Kühtreiber/Kühtreiber 2009, pp. 472-473 (with refs. to earlier literature); Skrabanek 2008, pp. 51-52, 63 ff. (comparison with Ungarschitz and other Strein castles). I am very grateful to Mr. Juergen Hesz for having generously allowed me full access to the house. 

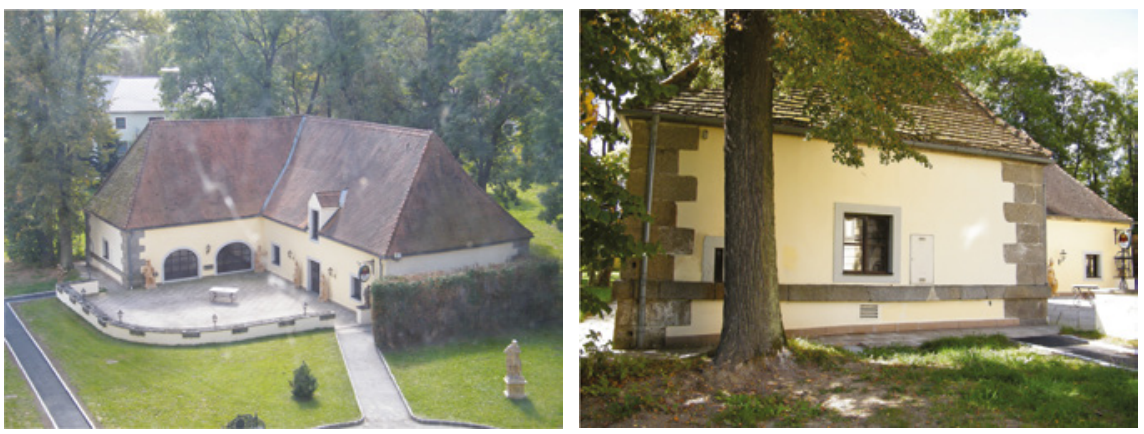

FIGURES 10.40-10.41 Schloss Schwarzenau: the one surviving bastion-like outbuilding.
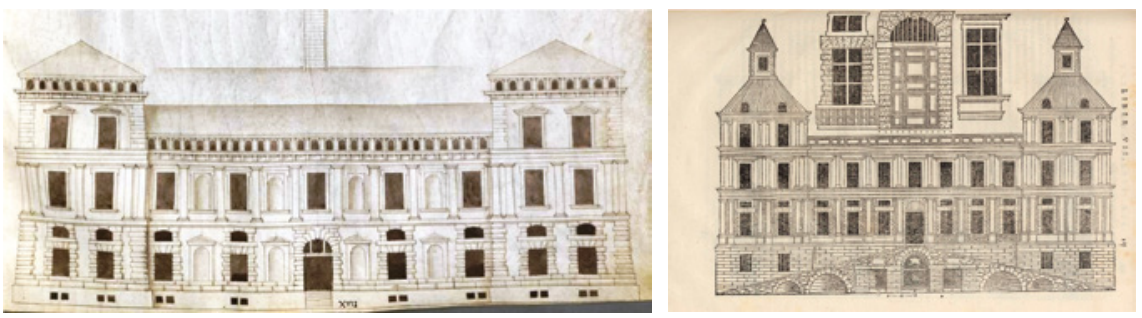

FIGURES 10.42-10.43 Sebastiano Serlio's non-executed designs for the châteaux at Ancy-leFrance (from the Sesto Libro) and Lourmarin (from the Settimo Libro).

by two huge square pavilions; above the two principal floors these develop into ample octagonal towers. It is not clear whether the original plan included a repetition of these pavilions at the north- and southeast corners. The semicircular courtyard seen in Vischer's print is probably a relic of the earlier castle which was intended to be eventually replaced (is has been demolished since then). ${ }^{38}$

In her recent thesis on the castle of Uherčice in Moravia, restructured for Reichard's brother Hanusch Wolfhart, Alena Skrabanek has compared the various projects undertaken by the Strein in these years. In an excursus she points out that in many of these projects various architectural details, in particular portals, are directly derived from illustrations in Serlio's treatises. ${ }^{39}$ She makes

38 Though it might be worthwhile to consider whether it may have been the relic of a planned, but unfinished circular courtyard as at the Villa Madama, the Palace at Granada, and in several of Serlio's palace projects. No remnants of this fabric appear to have survived.

39 Notably the portal of the church at Ferschnitz, the parish church next to Reichard's principal seat at Freidegg, and where he arranged the tombs for himself and his two wives; Skrabanek 2008, Ch. 10.5. 'Serliorezeption bei Bauten der Streun' pp. 94-100. 

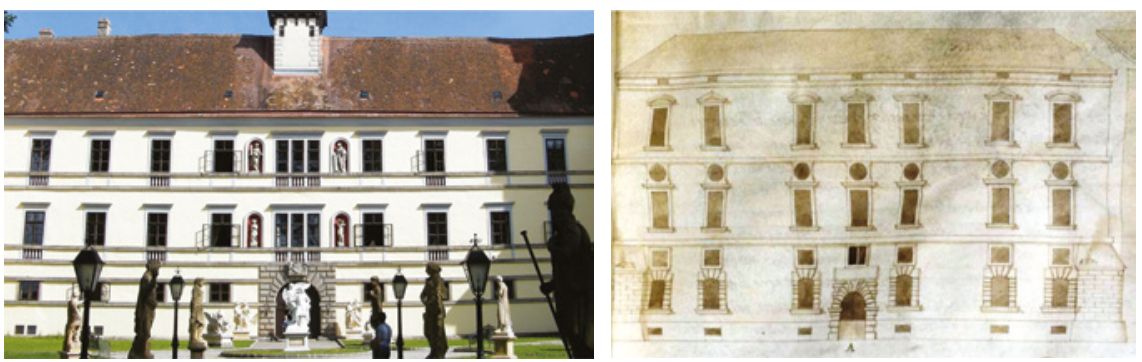

FIGURES 10.44-10.45 The entrance facade of Schwarzenau compared to Serlio's proposal for 'a house for a tyrant prince in the countryside' in his Sesto Libro.


FIGURES 10.46-10.47 A detail of the entrance facade of Schwarzenau, compared to one of Serlio's proposals for the refurbishment of an old town house, in his Settimo Libro.

no mention of Schwarzenau in this context, but a case can be made that here Serlio's example likewise provided some inspiration.

The castle at Schwarzenau is of a similar type as Bučovice, its lay-out another version of a 'palazzo in fortezza' as presented in Serlio's Sesto Libro [Fig. 10.22-10.23]. One of the bastion-like outbuildings at the angles of the forecourt, here placed quite close to the main building, is still preserved [Fig. 10.4010.41]. The type of the house, an ample facade flanked by huge square towers, is even closer to its type than is Bučovice.

This type itself is close to the type Serlio developed for two of his French patrons at the castles at Ancy-le-Franc and Lourmarin, likewise illustrated in the Sesto Libro and in the Settimo Libro respectively [Figs. 10.42 and 10.43]. Both here and in Schwarzenau - and at Bučovice for that matter-the corner blocks may have been inspired by the corner towers of the medieval castles these houses replace, but their bulk far exceeds that of such towers. Unlike as at, for instance, the Escorial, these towers have developed into pavilions, 

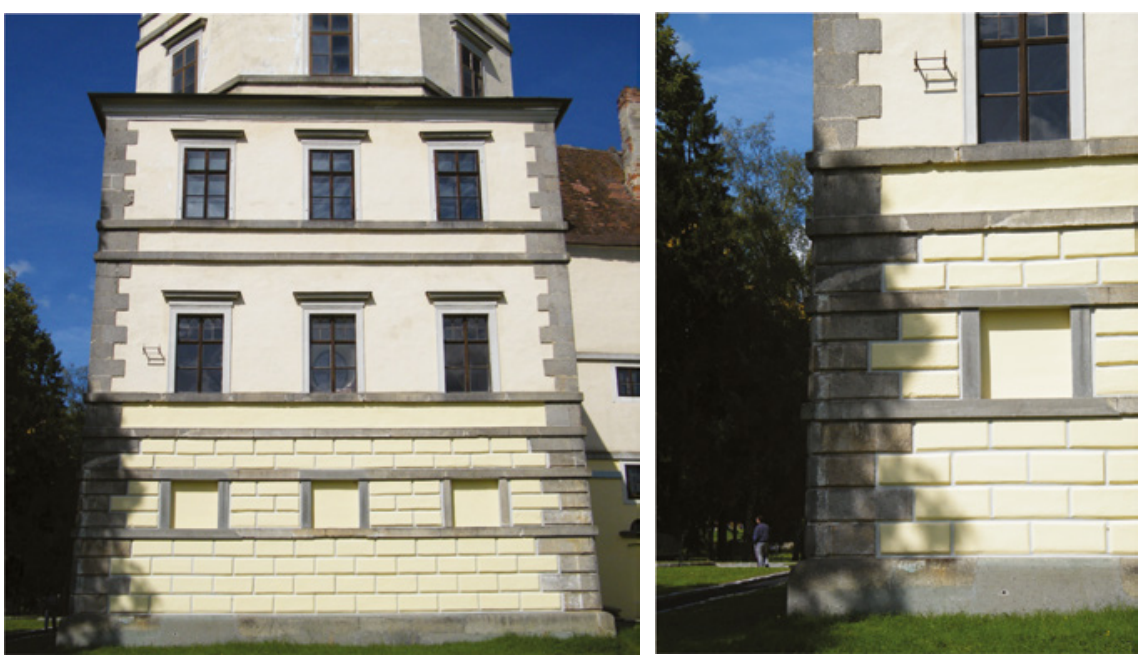

FIGURES 10.48-10.49 Schwarzenau: the southwest pavilion and a detail of its rustic story.

building blocks so substantial that they draw attention away from the centre of the building. It is not surprising that at Schwarzenau, where the pavilions are separated by a more extended front facade than in Serlio's designs, it was felt necessary to accentuate its centre with a bell tower on the roof.

The composition of the entrance facade at Schwarzenau also appears to reflect Serlian example. Though less markedly rhythmical, the placement of the windows accentuates the centre in a rather similar way as in Serlio's facade for a 'casa del principe tiranno' in the Sesto Libro [Figs. 10.44 and 10.45]. And its central bay seems a rather close variation on Serlio's eighth proposal for the refurbishment of an old town house in his Settimo Libro, down to the placement of the niches on either side of the Serliana (which at Schwarzenau is reduced to a minimal tripartite window) and the sparse detailing of the entrance portal [Figs. 10.46 and 10.47]. ${ }^{40}$

Apart from Serlio, Schwarzenau owes some of the elements of its design to Mantua, to the spare, well-proportioned architecture in modelled brick covered in stucco as it was developed by Giulio Romano and continued by his

40 It is not quite clear whether the four niches with statues of female personifications date from a later, Neoclassical refurbishment in the early nineteenth century; neither Vischer's image of the castle nor that in an eighteenth century painted wall-hanging discussed and illustrated in Donin 1963, pp. 73-75, are sufficiently clear to determine whether the niches were already there. But the Serlio example indicates that it is perfectly plausible that they were. Physical investigation of the niches themselves and of the four statues (are these the originals?) might contribute to an answer to this problem. 

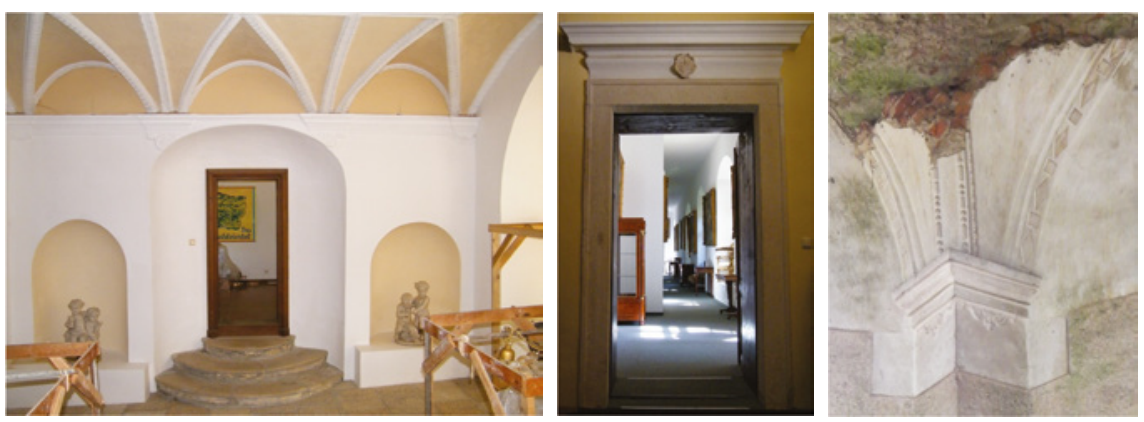

FIGURES 10.50-10.52 Schwarzenau: the entrance to the ground floor from the androne; a door surround on the first floor; remains of the stucco ceiling in one of the octagonal rooms in the north-west pavilion.

pupils Giovanni Battista Bertani and Ippolito Pedemonte. Note in particular the carefully designed and beautifully proportioned corner pavilions, and the flat bugnato of the rustic level [Fig. 10.48-10.49]. The strongly marked, heavy stone string courses, emphasizing the horizontals of the facade and pulling the whole building together, are another Mantuan feature. It is moreover an element which immediately links Schwarzenau to the design of the Vienna Neugebäude [above, Fig. 9.105-9.106].

The careful detailing is a quite exceptional feature of Schwarzenau: elements such as the elegant niches flanking a segmental entrance portal in the androne [Fig. 10.50], the well proportioned door-surrounds [Fig. 10.51] and some of the remains of the stucco decorations [Fig. 10.52] are purely classical and Italian in taste. Over all the design of Schwarzenau is of exceptional quality: it demonstrates a profound grasp of the principles of classical, Vitruvian architecture, and no concessions are made to vernacular tradition. ${ }^{41}$ This sophistication well fits the patron, an intellectual aristocrat who may well have owed this sophistication in the field of architecture not only to a first-hand knowledge of printed architectural treatises, but also to his familiarity with the many materials he had seen in Strada's Musaeum and to the explanations and comments their owner had provided.

Whether Strein had asked Strada to prepare designs for his project cannot be determined. I am inclined to think that this has been the case, in the first

41 Alena Skrabanek signals a similar understanding in the use of Serlio's example in other commissions of Strein and his brothers: 'Die nicht mehr wörtliche Übernahme des Vorbildes bei den weiteren Anwendungen zeugt von einem tieferen Verständnis der Lehre des Traktates, dessen Gebrauch zwar für eine praktische Benützung, aber nicht für ein geistloses Nachbauen der dort illustrierten Exempel gedacht war'. (Skrabanek 2008, p. 95). 
place because there are few-if any-other architects in the region to whom it could plausibly be attributed; but also because its style is quite close to what one could expect from Strada on the basis of his architectural backgroundMantua, Giulio and Serlio - and of the little we know of his architectural practice, in particular his drawings for the Munich Antiquarium and the design of his own house in Vienna.

\subsection{Conclusion}

The exact significance of Jacopo Strada's position as Imperial Architect is very difficult to determine with certainty, chiefly because it appears that he was hardly - if ever-employed as an executive architect or master mason actually supervising the construction of his projects. There is little concrete information even on his role as a designer, which is documented only for the Munich Antiquarium and an unspecified section of the Vienna Neugebäude, and is self-evident in the case of his own house. Moreover Strada himself hardly presented himself as an architect: he preferred to sign with his title as Imperial Antiquary, and even in his Serlio edition he did not present himself as an architect or builder, but merely implied that he was capable of editing Serlio's drawings 'because of the familiarity I have with his things'. Though well aware of the importance of constructive and technical aspects of building and quite adept at practical detailing in an architectural design, as the Antiquarium design makes abundantly clear, it is obvious that he did not consider himself a builder or contractor. It is unlikely that he ever acted as such, except in the case of his own house. It was only towards the end of his career, when his other activities had became less lucrative, that he explicitly solicited for architectural commissions, first with the Elector August of Saxony, and later with Archduke Ernest, as governor of Lower and Upper Austria for his brother, Emperor Rudolf II. In neither case there is evidence that his attempts were successful, though in view of the type of services he offered, this absence of documentation does not necessarily imply that they were not. Advice given, a sketch or even a worked-out design made at an informal request, an expert coaching given to a fellow court-architect in the guise of collegial consultation are not things that necessarily are recorded on paper. ${ }^{42}$

42 Hilda Lietzmann 1997 exhaustively presents the evidence of Strada's contact with the Dresden court, and makes a quite convincing case that Strada did not get very far with Elector August, who had just appointed a new, young Italian architect, Giovanni Maria Nosseni. But here again we only know what happened before Strada actually met the Elector in person. For Strada's approach to Archduke Ernest in 1579, cf. above, Ch. 4.4.1; it is not unlikely that the Archduke did occasionally employ him even in the 1580s: as a 
In any case this lack of practical building experience by no means precludes his immediate influence on the architectural patronage at the Imperial court and its Umkreis. Strada is certainly not the only Renaissance architect who did not come to the job out of the building industry: Alberti, Michelangelo, Raphael and Giulio Romano are merely the most exalted examples. There can be no doubt that Strada's role as an architectural designer was taken seriously at court: the trouble Maximilian II took during his last diet at Regensburg, only a few weeks before his death, to recommend his faithful servant to Elector August of Saxony is sufficient evidence of his confidence in Strada's powers.

Summing up, we may conclude that Strada's position as an Imperial Architect and as an expert in the design both of classical Antiquity and contemporary Italian architecture and decoration cannot have failed to have had a certain significance. His position was so firm, his network so wide, that it can be confidently assumed that he had a considerable influence on the development of architecture and decorative design at the Imperial court, and occasionally elsewhere in Austria and Bohemia. This effect was linked to the tastes and preferences of his chief patrons, the Emperors Ferdinand I and Maximilian II, and on those of a select group of their courtiers. Moreover his expertise may have influenced the architects and other artists active at court.

Strada exerted such influence partially by means of his own example: at least by the splendid house he built for himself. But doubtless of far greater importance was the collection of relevant graphic documentation on classical Antiquity and contemporary art, architecture and decoration that was housed in it, and which was accessible at least to the upper ranks of courtiers and to Strada's immediate colleagues. These materials were instructive in themselves, but in view of Strada's enthusiasm for his drawings, it is quite likely that he would explain them to, and critically discuss them with his visitors. In this way his Musaeum provided a modest and informal academy of architecture and design. It is for this, perhaps more than for his own designs, that Strada can be considered as an important channel by which the ideas and the formal language of the Italian High Renaissance came to be received in Central Europe. This was only one function of the minor but quite lively centre of artistic and intellectual activities that his house and collection offered to the Imperial court and its many visitors, and which will be sketched in the next chapters of this study.

resident of Vienna he was close at hand, and through his eldest son Paolo was represented in the household of the Archduke Ernest, who may also have occasionally referred to him purely out of courtesy to an old, faithful servant once highly prized by his father. 